\title{
Kati Hannken-Illjes: Argumentation. Einführung in die Theorie und Analyse der Argumentation. Narr/Francke/ Attempto: Tübingen, 2018, 193 pp
}

\section{Manfred Kienpointner ${ }^{1}$ (D)}

Published online: 24 January 2019

(c) The Author(s) 2019

This book is an introduction into the theory and analysis of argumentation. Although quite a few introductions into these issues are already available in German, Hannken-Illjes' book does fill a gap: First of all, it focuses on the rhetorical and dialectical approaches to the theory and analysis of argumentation, dealing with the logical perspective only very briefly (cf. pp. 32-35). This can be justified by the fact that there already are several valuable introductions in German which deal with (formal) logic and argumentation (cf. e.g. Bayer 2007; Tetens 2014; Walter and Wenzl 2016). Secondly, the rapid development and the thematic expansion of rhetorical and dialectical contributions to the study of argumentation within the last few years call for a comprehensive introduction, which so far has not been available in German.

As far as the English-speaking world is concerned, the Handbook of Argumentation Theory (van Eemeren et al. 2014) is an admirably comprehensive presentation of all theoretical, empirical and practical approaches in argumentation studies (where also contributions from outside of the Anglophone countries are dealt with, cf. pp. 677ff.).

However, as far as rhetorically and/or dialectically orientated introductions to the field of argumentation written in German are concerned, Kopperschmidt (1989, 2000) does not cover the more recent developments, Göttert (2009) is focussed on ancient rhetoric and its reception in medieval and modern times, and Posch (2014) is a more practically orientated introduction for students. Finally, Mihajlovic (2008) has a more specific focus on central concepts of argumentation theory and logic. This situation makes Hannken-Illjes' book most welcome and a contribution which fills a gap in the German speaking area.

In the first chapter (introduction), Hannken-Illjes describes the overall goal of her book, namely, to provide an accessible and comprehensive overview of the rhetorical and dialectical theories, approaches, traditions, and the corresponding research

Manfred Kienpointner

Manfred.Kienpointner@uibk.ac.at

1 Department of Languages and Literatures, University of Innsbruck, Innsbruck, Austria 
traditions which currently are typical for the field of argumentation studies (pp. 11f.). In order to enhance the accessibility of the book and to provide interesting and enlightening examples, Hannken-Illjes chose to use Horst Budjuhn's German version of the drama Twelve Angry Men by Reginald Rose (1920-2002; a feature film adaptation was directed by Sidney Lumet 1957, starring Henry Fonda). The play shows the controversial deliberations of the jury of a homicide trial against a young man accused of having stabbed his father. This choice made by Hannken-Illjes can be listed among the numerous strengths of the book: The quoted passages are highly suitable for attracting the reader's interest and for illustrating a wide range of rhetorical and argumentative phenomena.

The second chapter contains a definition of argumentation (p. 20: "Argumentation ist die Bearbeitung einer Streitfrage durch das Geben und Nehmen von Gründen", that is, "Argumentation is the treatment of a controversial issue by giving and taking grounds"). The argument as the basic unit of argumentative activities is described by a model with three elements: a ground, a warrant and a conclusion (pp. 22ff.). Hannken-1lljes proceeds with a discussion of Wenzel's (1990) well-known trichotomy of a logical, a dialectical and a rhetorical perspective of argumentation, namely, as a product, a procedure and a process, respectively. The logical perspective is only very briefly presented here (pp. 32-35).

Chapter 3 treats the dialectical perspective, which tends to be normative. Hannken-Illjes gives an overview of the theories and approaches of Informal Logic (including the work of Douglas Walton), Critical Thinking, Fallacy Theory, Normative Pragmatics, Jürgen Habermas, Arne Naess and, in some more detail, PragmaDialectics, including the recent attempts to integrate a dialectical and a rhetorical perspective by the Extended Theory of Pragma-Dialectics, and by Christopher Tindale (pp. 70ff.).

Chapter 4 treats the rhetorical perspective, which tends to be effectiveness-oriented, though not without various reservations, including some normative aspects, too (p. 75). Hannken-Illjes first deals with basic Aristotelian distinctions such as the trichotomy of logos, ethos and pathos and the dichotomy of enthymeme and paradeigma. Then she proceeds to critically discuss Stephen Toulmin's approach and the New Rhetoric developed by Chaim Perelman and Lucie Olbrechts-Tyteca.

The last part of chapter 4 is devoted to a more specific issue, treated both in dialectical and in rhetorical approaches, namely, the topoi, an concept developed both in Aristotle's Topics and in his Rhetoric. Although not clearly defined in Aristotle's texts, topoi can be seen both as search formulas used to find arguments and as inference warrants guaranteeing the relevance of the arguments. Hannken-Illjes considers the heuristic function to be the more basic one (p. 100). She also treats Perelman and Olbrecht-Tyteca's (1983) typology of argument schemes, which is based on Aristotle's Topics and Rhetoric.

In chapter 5 Hannken-Illjes presents a valuable and admirably comprehensive overview about methods for analysing arguments. Five aspects of analysis are distinguished (pp. 115f.): (1) the analysis of the controversial issues/points of view (based on distinctions developed by ancient status theory); (2) the functional analysis, which deals with the role of utterances within a basic model of argumentation, such as the Toulmin model (micro level), and with the description 
of the structure of complex argumentation (macro level), including the problem of the reconstruction of implicit premises of an argument; (3) the "material" analysis, where argumentative utterances are assigned their role as parts of argument schemes and topoi; (4) the conversational analysis, which focusses on argumentation as a process within a dialogue, and describes the activities of persons involved in that dialogue, their relationship, the mechanisms of turn taking, and the stages of the ongoing process; (5) the ethnography of argumentation, where argumentation is described as a problem-solving activity within a certain field.

The last chapter (ch. 6) provides an overview of three current trends within contemporary argumentation studies: (1) the relationship between argumentation and narration, (2) the multimodal analysis of argumentation, (3) the treatment of deep disagreement and incommensurability.

From antiquity onwards, the argumentative functions of narrative elements of texts (factual or fictional stories) have been studied. Hannken-Illjes presents an overview of recent approaches and analyses concerning the interplay of narration and argumentation, including the problem of clearly distinguishing between factuality and fictionality.

The seminal work of Groarke (1996, 2002) and Groarke et al. 2016) has created an increasing trend to study nonverbal forms of argumentation, especially visual argumentation, or combinations of verbal and visual arguments (multimodal analysis). Hannken-Illjes extends this approach with interesting reflections (pp. 167ff.) on the argumentative aspects of human voice and the use of material objects as "inartificial" elements of proofs in the Aristotelian sense.

The controversial issue of the possibility of incommensurability as a limit of argumentation is treated both at the theoretical level and as far as practical solutions of the respective problems are concerned.

As this summary of the content of Hannken-Illjes' book has already shown, she has provided us with a well-written and comprehensive overview of current trends in argumentation research based on a dialectical and/or rhetorical perspective. Of course, given the wealth of publications in this field, true exhaustiveness has become almost impossible. But Hannken-Illjes at least treats the most important theories and traditions, always combined with a critical, but fair discussion of these approaches. She also adds useful remarks on innovative developments within the field, such as the concept of strategic maneuvering as a recent extension of the standard theory of Pragma-Dialectics (p. 70), the valuable input of conversation analysis and the ethnography of communication to argumentation studies (p. 141, p. 145), and, with the treatment of narration, multimodality and deep disagreement, she has chosen three recent issues within the study of argumentation which are important and highly interesting (pp. 153ff.).

Therefore, her book can be recommended as a highly valuable, theoretically thorough, and at the same time accessible introduction, both for specialists in the field of rhetoric and argumentation, who want to keep up with recent research trends, and for newcomers from disciplines such as linguistics, communication studies, philosophy and social sciences. 
The following critical remarks do not call into question this very positive evaluation, but should be seen as suggestions for modifications within and additions to a future revised edition of the book.

1. In spite of the fact that this is decidedly not the focus of the book, the very brief remarks on the logical perspective (pp. 32ff.) could be supplemented by giving a few more examples for logically valid inference schemes, such as Modus ponens (only mentioned implicitly on p. 33), Modus tollens, and Disjunctive Syllogism, as these schemes come closer to the structure of everyday argumentation than the example of Modus Barbara given on p. 35. Dialogue logic (for an excellent overview, cf. e.g. Krabbe 2006) could already be mentioned within the short chapter on the logical perspective, as Dialogue Logic is briefly referred to later on (on p. 43).

2. As far as Aristotle's well-known trichotomy of logos, ethos and pathos is concerned, Hannken-Illjes correctly states that Aristotle's does basically treat them as equally plausible means of persuasion. However, considering the specific role ("besondere Rolle", p. 77) of the enthymeme, that is, logos, she could underline this specific role even more, as Rapp has given good reasons for the central role of logos in his commentary on Aristotle's Rhetoric (cf. Aristotle 2002: 356f.).

The statement that the Topics is primarily "eine Such- und Findekunst" ("an art of invention and finding"; p. 100) might underestimate the second function of the Aristotelian topos, namely, to function as a bridging statement, that is, as a warrant in the sense of Toulmin's model (cf. de Pater 1965, which is a brilliant and, according to me, still valid interpretation of the Aristotelian topos; cf. also Sklomkowski 1997: 2; Rubinelli 2010: 23; van Eemeren et al. 2014: 68f.).

3. As far as the typology of controversial issues/standpoints is concerned, the distinctions made by Pragma-Dialectic in order to classify standpoints should be briefly mentioned, too (cf. van Eemeren 2010: 1ff).

4. Although I remain sceptical about the relativist implications of his work, the important contributions by Michel Foucault concerning the "archaeology of knowledge" (cf. e.g. Foucault 1969) should be taken into account within the discussion of the ethnography of knowledge (p. 146).

5. Finally, a few typing/printing mistakes should be corrected: on p. 34, the correct form of the name is "Charles Sanders Peirce"; on p. 104, it should be "Sieveke"; on pp. 164, 166, 172, 181 it should be "Groarke".

Open Access This article is distributed under the terms of the Creative Commons Attribution 4.0 International License (http://creativecommons.org/licenses/by/4.0/), which permits unrestricted use, distribution, and reproduction in any medium, provided you give appropriate credit to the original author(s) and the source, provide a link to the Creative Commons license, and indicate if changes were made. 


\section{References}

Aristoteles 2002. Rhetorik. Translation and Commentary. by Chr. Rapp. vol. 1. Berlin: Akademie Verlag. Bayer, Klaus. 2007. Argument und Argumentation. Logische Grundlagen der Argumentationsanalyse, 2nd revised ed. Göttingen: Vandenhoeck \& Rupprecht.

De Pater, Wilhelm A. 1965. Les Topiques d'Aristote et la dialectique platonicienne. Fribourg: Éditions St. Paul.

Foucault, Michel. 1969. L'archéologie du savoir. Paris: Gallimard.

Göttert, Karl-Heinz. 2009. Einführung in die Rhetorik: Grundbegriffe-Geschichte -Rezeption, 4th revised ed. München: Fink.

Groarke, Leo. 1996. Logic, Art and Argument. Informal Logic 18(2): 105-129.

Groarke, Leo. 2002. Towards a Pragma-Dialectics of Visual Argument. In Advances in Pragma-Dialectics, ed. F.H. van Eemeren, 137-151. Amsterdam: SicSat.

Groarke, Leo, Catherine H. Palczewski, and David Godden. 2016. Navigating the Visual Turn in Argument. Argumentation and Advocacy 52(4): 217-235.

Kopperschmidt, Josef. 1989. Methodik der Argumentationsanalyse. Stuttgart: Frommann und Holzboog.

Kopperschmidt, Josef. 2000. Argumentationstheorie zur Einfuihrung, 3rd ed 2014. Hamburg: Junius.

Krabbe, Erik. 2006. Dialogue Logic. In Handbook of the History of Logic, vol. 7, ed. D.M. Gabbay and J. Woods, 665-704. Amsterdam: Elsevier.

Mihajlovic, Milan. 2008. Argumentation: Grundbegriffe, Logik und Anwendungen. Aachen: Shaker.

Perelman, Chaim, and Lucie Olbrechts-Tyteca. 1983. Traité de l'argumentation. Bruxelles: Éditions de l'Université de Bruxelles.

Posch, Claudia. 2014. Argumentieren, aber richtig. Praxisbuch für Studierende. Tectum: Marburg.

Rubinelli, Sara. 2010. Ars Topica. Dordrecht: Springer.

Sklomkowski, Paul. 1997. Aristotle's Topics. Leiden: Brill.

Tetens, Holm. 2014. Philosophisches Argumentieren. Eine Einführung, 4th revised ed. München: Beck.

van Eemeren, Frans H. 2010. Strategic Maneuvering in Argumentative Discourse. Amsterdam: Benjamins.

van Eemeren, Frans H., B. Garssen, E.C.W. Krabbe, F.A. Snoeck Henkemans, B. Verheij, and J.H.M. Wagemans. 2014. Handbook of Argumentation Theory. Dordrecht: Springer.

Walter, Paul, and Petra Wenzl. 2016. Kritisch denken-treffend argumentieren. Wiesbaden: Springer.

Wenzel, Joseph. 1990. Three Perspectives on Argument. Rhetoric, Dialectic, Logic. In Perspectives on Argumentation, ed. R. Trapp and J. Schuetz, 9-26. Prospect Heights: Waveland.

Publisher's Note Springer Nature remains neutral with regard to jurisdictional claims in published maps and institutional affiliations. 